STUDIA HISTORYCZNE

R. $L X, 2017, z .4(240)$, s. $65-78$

\title{
ARTYKU€ RECENZYJNY
}

\author{
Waldemar Kowalski
}

Uniwersytet Jana Kochanowskiego, Kielce

\section{RZECZPOSPOLITA W EUROPIE, CZYLI O OTWARTOŚCI I POTRZEBIE DIALOGU KULTUR UWAGI PO LEKTURZE DWÓCH TOMÓW
SERII WYDAWNICZEJ KULTURA PIERWSZEJ
RZECZYPOSPOLITEJ W DIALOGU Z EUROPA}

Tomy I i II serii wydawniczej Kultura Pierwszej Rzeczypospolitej w Dialogu z Europa ${ }^{1}$ traktować można jako sumę wiedzy o więzach łączących narody Królestwa Polskiego, a następnie państwa polsko-litewskiego z innymi narodami naszego kontynentu. Zasadniczym aspektem takich relacji jest obecny w tekstach wszystkich autorów wszechstronny ogląd universum vite christinane. Ten dynamiczny obraz przedstawiony został w pełni swego bogactwa: jako stosunek do tradycji, programów konfesyjnych i społecznych, zaś cel i zasięg komentowanych wypowiedzi szeroko zakreśla krąg ich adresatów.

Czytelnik poznający zarys projektu badawczego, który otwiera pierwszy tom serii, z akceptacją i nadzieją wita zapowiedź uczestnictwa w dialogu autora z wybranymi przezeń tekstami. Jest to zaproszenie do refleksji nad trudem badacza i jego efektem w klimacie inspiracji, który - jak przypomniał przed laty Janusz Gruchała - iucunda familia librorum dawała niegdyś humanistom ${ }^{2}$. Historyk przemian społecznych jako naturalne przyjmuje postępowanie

W'ród krajów Pótnocy. Kultura Pierwszej Rzeczypospolitej wobec narodów germańskich, stowiańskich i naddunajskich. Mapa spotkań, przestrzenie dialogu, red. M. Hanusiewicz-Lavalle e, Warszawa 2015, Kultura Pierwszej Rzeczypospolitej $w$ dialogu z Europa. Hermeneutyka wartości, t. 1, red. A. Nowicka- Jeżowa; W przestrzeni Potudnia. Kultura Pierwszej Rzeczypospolitej wobec narodów romańskich. Estetyka, prady i style, konteksty kulturowe, red. M. Ha nu si e wi cz-Lavalle e, Warszawa 2016, Kultura Pierwszej Rzeczypospolitej..., t. 2.

2 J.S. G r u chała, Iucunda familia librorum. Humaniści renesansowi w świecie ksią̇ki, Kraków 2002. 
badawcze, które w studiach historycznoliterackich, być może, ciągle wymaga jednoznacznej artykulacji: oddzielenie tekstu z epoki od jego „otoczenia historycznego nie jest możliwe ani właściwe”. Przypominając, że „przedmiotem heurezy jest nie tylko sam tekst, lecz także jego kulturowe uobecnienie", Alina Nowicka-Jeżowa ${ }^{3}$ nie bez racji wskazuje, aby postępować drogą, którą w polskiej nauce historycznej wytyczyli przed laty mediewiści, m.in. Brygida Kürbis4. Interdyscyplinarne postrzeganie dawnych więzi kulturowych jest już dobrą praktyką polskiej humanistyki, a oba dyskutowane tu tomy to wielce wartościowe dopełnienie tej tradycji.

Ze wszech miar słusznie więc koncepcja całego projektu nie ograniczyła się do śledzenia wąsko pojętych kontaktów literackich. Dyskusyjne pozostaje jednak pominięcie w obu tomach szerokiej sfery zagadnień wzajemnego oddziaływania słowa i obrazu, a zaliczyć należy doń źródła heraldyczne, jak m.in. najstarsze role herbowe oraz kompozycje emblematyczne. Dostrzec tu można również zagadnienie ilustracji tak powszechnie powielanych na przełomie średniowiecza i nowożytności treści jak ars moriendi $i^{5}$ Korzyści płynące z dalszych takich studiów szczegółowych dla lepszego zrozumienia religijności średnich warstw społecznych są bezdyskusyjne ${ }^{6}$. Podjęte w obu recenzowanych tomach próby zakreślenia horyzontów dalszych badań nie pozostały bezproduktywne. Cztery interesujące teksty poświęcone kontaktom polsko-hiszpańskim każą sądzić, że choć wzajemne relacje między obu królestwami były raczej nikłe, to zasadne jest dalsze poszukiwanie miejsc, w których kultury ich narodów mogły na siebie oddziaływać za pośrednictwem choćby włoskich miast i tamtejszych uniwersytetów ${ }^{7}$. Niewątpliwą zaletą omawianych tomów jest więc wskazywanie nowych przestrzeni badawczych.

Lektura artykułów składających się na tom pierwszy, poświęcony związkom kultury Rzeczypospolitej z narodami germańskim, słowiańskimi i naddunajskimi, prowadzi do wniosku, że o natężeniu takich relacji nie przesądzały ani bliskość języków wernakularnych, ani tożsamość wyznaniowa czy też zasięg wpływów antycznego dziedzictwa i kultury włoskiego renesansu. Niejednakowo ważył nawet czynnik geograficznej bliskości.

A. Now ick a -Jeżow a, Ad lectorem. Zarys projektu badawczego, [w:] W'sód krajów Pótnocy, s. 41.

4 B. Kü r b is, Metody źródtoznawcze wczoraj i dziś, [w:] e a d e m, Cztery eseje o źródtoznawstwie, wstęp i dobór tekstów R. Witkow ski, Poznań 2007, s. 104-119, Klasycy Nauki Poznańskiej, t. 13, red. A. Pi ha n- Kijasowa.

5 Konieczności widzenia takich polskich zabytków w szerszym międzynarodowym kontekście dowodzą choćby tak podstawowe opracowania, jak: J. Pelc, Stowo i obraz na pograniczu literatury i sztuk plastycznych, Kraków 2002; M. W ło d a rski, Obraz i stowo. O powiąaniach w sztuce i literaturze XV-XVI wieku na przyktadzie „ars moriendi”, Kraków 1991.

6 A vista wskazać można tu cenne opracowanie K. Krzak (Pobożność popularna w ilustracjach modlitewników drukowanych w Polsce XVI wieku, [w:] Sztuka okoto 1500. Materiaty sesji Stowarzyszenia Historyków Sztuki. Gdańsk, listopad 1996, red. T. H ra n kowsk a, Warszawa 1997, s. 299-312).

7 J. Kieniewicz, Hiszpania a Rzeczpospolita, [w:] W przestrzeni Potudnia..., s. 387-404; M. Urjasz- Raczko, Duma i uprzedzenia. Strategia dyplomacji hiszpańskiej wobec pierwszych wolnych elekcji w Rzeczypospolitej, [w:] ibidem, s. 405-429; J. Pa r ty k a, Kobiety a hiszpańska obecność w kulturze dawnej Rzeczypospolitej. Wybrane aspekty, [w:] ibidem, s. 430-448 oraz M. Wojt y n iak, Rzeczpospolita i Hiszpania w kregu europejskiej respublica litteraria, [w:] ibidem, s. 449-468. 
Uwarunkowania te jawią się z różną mocą w zależności od miejsca i czasu, ale - jak prawie wszyscy autorzy stwierdzają expressis verbis - nader istotną rolę pełniły stosunki polityczne, a chyba niesłusznie z mniejszą siłą akcentowane są w tym kontekście więzi gospodarcze.

Kilka poniższych refleksji dotyczy następujących kwestii: co powodowało, iż różne było natężenie szeroko pojętych relacji kulturowych, które ściślej lub słabiej łączyły ówczesnych Polaków z narodami europejskimi, dlaczego taka oferta Rzeczypospolitej wzbudziła dość ograniczone zainteresowanie społeczeństw zachodniej Europy, a nadto kto był, czy też mógł być, odbiorcą takich nowości? Wyeksponowanie w tym kontekście dziejów Wysp Brytyjskich wynika nie tylko ze względnej obcości kulturowej narodów zamieszkujących wschodnie i zachodnie obrzeża Christianitatis occidentalis w czasach nowożytnych, ale także z kompetencji badawczych autora tego omówienia.

Przedstawione w tomie I wypowiedzi prowadzą do niezbyt odkrywczego wniosku, że ówczesną, nazwijmy to, wymianę wartości kulturowych silnie determinowały podziały wyznaniowe. Wśród wiernych Rzymowi bezsprzecznie pierwszoplanową pozycję w transferze tych wartości ma Towarzystwo Jezusowe, potężne intelektem pierwszych pokoleń zgromadzenia. Kontrreformacyjna czy szerzej duszpasterska aktywność tych księży stanowi o witalności ówczesnego katolicyzmu, szczególnie w XVI wieku i pierwszych dekadach XVII stulecia. Europejskim rozgłosem cieszy się wszechstronnie utalentowany Maciej Kazimierz Sarbiewski, a poza nim raczej już tylko zmarli w opinii świętości polemiści oraz pisarze ascetyczni: Mikołaj Łęczycki (zm. 1653) i Kasper Drużbicki (zm. 1662). Wkład innych piszących i publikujących polskich księży katolickich do bogactwa duchowego powszechnego Kościoła jest dalece skromniejszy - szczególnie w zestawieniu z takim gigantem intelektu jak Stanisław Hozjusz. Oczywiście, wymienić można jeszcze kilku autorów, których prace ogłaszane były z myślą o zachodnim odbiorcy, jak przykładowo Marcin Kromer. Nie zmienia to faktu, iż gwiazda polskich teologów katolickich, jeśli rozbłysła na europejskim firmamencie, to raczej krótkotrwałym blaskiem. Aby jednak przeciwstawić się łatwym i upraszczającym rzeczywistość uogólnieniom, przywołajmy Jana Dantyszka, postać o wyjątkowym znaczeniu dla ówczesnego polskiego władcy, Kościoła oraz europejskiej kultury ${ }^{8}$.

$\mathrm{Na}$ tym tle udział polskich teologów ewangelickich w dziele budowy europejskiej reformacji jawi się wielce skromnie, a jego właściwą ilustracją jest Międzynarodowy Pomnik Reformacji w Genewie, gdzie jako jedyny reprezentant Rzeczypospolitej Obojga Narodów upamiętniony został Jan Łaski młodszy. Doceniając poruszenie wywołane edycjami niemiecką (1608) i lacińską (1609) katechizmu rakowskiego9, aktywność ariańskich egzulantów oraz znaczenie dzieł zebranych w serii wydawniczej Bibliotheca Fratrum Polonorum (1668-1692), pamiętać jednak trzeba, że była to inspiracja elitarna, a z ówczesnej szerszej

8 Zob. Z. Now ak, Jan Danyszek. Portret renesansowego humanisty, Wrocław 1982, Biblioteka Towarzystwa Przyjaciót Gdańska.

9 O tym m.in. M. Pawele c, Barttomiej Bythner starszy (ok. 1559-1629). Z dziejów protestanckiego irenizmu na przetomie XVI i XVII wieku, Warszawa 2008, s. 51. 
europejskiej perspektywy raczej nie pierwszorzędnego znaczenia. Ożywczy wpływ antytrynitaryzmu na ferment intelektualny w ówczesnej Europie nie ulega wątpliwości ${ }^{10}$. Nauka Socyna oraz poglądy innych polskich antytrynitarzy nie mogły jednak w ówczesnej rzeczywistości formować postaw społecznych w tak szerokim zakresie, jak teologie ewangelickie czy katolicyzm. Polski ruch reformacyjny nie dał Europie wybitnych teologów (w szerszym pojęciu tego słowa). Uwiąd tego ruchu, postępujący od przełomu XVI/XVII stulecia, a przyczyny tego omawiano wielokrotnie, miał też - mym zdaniem - negatywny wpływ na rozwój katolickiej myśli teologicznej. Wojciech Kriegseisen wspomniał nie tak dawno temu „bezrefleksyjny typ katolickiej duchowości kontrreformacyjnej” ${ }^{11}$. Podkreślić jednak należy, że studia nad katolicką literaturą apologetyczną, która powstawała w państwie polsko-litewskim w XVI-XVIII wieku, są bardzo słabo zaawansowane. Seria wydawnicza, której częścią są przedstawiane tu tomy, nie tyle istotnie zmienia ten stan rzeczy, co dobitnie podkreśla konieczność podjęcia systematycznych studiów w tym zakresie ${ }^{12}$. Przykładowo wnikliwej analizy nie doczekało się dotąd jedno z najbarwniejszych świadectw religijności Polaków przełomu średniowiecza i czasów nowożytnych, jakim jest katechizm Benedykta Herbesta $^{13}$. Ten bodaj najpełniejszy polski szesnastowieczny podręcznik podstaw dogmatyki katolickiej kierowany do duchowieństwa parafialnego i świeckich przegrał, choć nie od razu, z katechizmem rzymskim z powodów, które trudno szerzej omawiać w tym miejscu.

Opinię Wojciecha Kriegseisena odniósłbym więc raczej do czasów, gdy ustała już dość burzliwa, i powiedzielibyśmy dziś, niekoniecznie zawsze merytoryczna dyskusja nad zagadnieniami wiary i zbawienia. Jak słusznie stwierdził Piotr Wilczek, „przełom wieków XVI i XVII to rzeczywiście ostatni okres, w którym polemika była wprawdzie bezkompromisowa, ale obie strony trzymały się zasady plus ratio quam vis”. Nie negując osądu tego autora, iż „znaczenie polskich polemik wyznaniowych XVI-XVII wieku sięga daleko poza wymiar lokalny" ${ }^{14}$, podkreślić trzeba konieczność uściślenia kryteriów takich ocen. Obrona stanowiska, że

10 Szczególnie w świetle najnowszych ustaleń badawczych zebranych w tomie $\mathrm{X}$ interesującej nas serii $A n$ tytrynitaryzm w Pierwszej Rzeczypospolitej, red. M. Choptiany, P. Wilczek, Warszawa 2015. Na oddziaływanie socynianizmu na Wyspach Brytyjskich zwraca także uwagę M. Ha nusiewicz-Lavallee (Brytania i Sarmacja - na krańcach Europy, [w:] W'ród krajów Pótnocy, s. 147-151).

11 W. Krieg se is en, Autonomia jednostki a wolność sumienia. Problem konwersji w nowożytnej Rzeczypospolitej, [w:] Autonomia jednostki w Europie i w Polsce od XVII do XX wieku, red. W. Mę d r z e ck i, Warszawa 2011, s. 36 (25-44).

12 Podstawą tej opinii jest m.in. wartościowy przegląd autorów i tekstów zamieszczony w szkicu E. Buszewicz (Koncepcja jedności Kościota i idea Polski katolickiej w twórczości pisarzy potrydenckich, [w:] Formowanie kultury katolickiej $w$ dobie potrydenckiej. Powszechność i narodowość katolicyzmu polskiego, red. J. Dąb kow ska-Kujko, Warszawa 2016, s. 388-434, Kultura Pierwszej Rzeczypospolitej..., t. 6).

13 B. Herbest, Nauka prawego chrześcijanina, Kraków 1566. O Herbeście zob. H. E. Wy c zaw sk i, Herbest (Herbestus, Neapolitanus) Benedykt, [w:] Stownik polskich teologów katolickich, t. 2, red. H. E. Wyczaw ski, Warszawa 1982, s. 36-37; S. Ra b i j, Herbest, Herbestus Neapolitanus, Benedykt SJ, [w:] Encyklopedia katolicka, t. 4, red. J. Walkusz, Lublin 1993, kol. 741.

14 P. Wilczek, Polonice et Latine. Studia o literaturze staropolskiej, Katowice 2007, s. 74. 
obecnie niewiele na to wskazuje, szczególnie w odniesieniu do drugiego z wymienionych stuleci, nie wydaje się zadaniem niewykonalnym. Klimat intelektualny pierwszych dekad XVII wieku nie sprzyjał dyskusjom nad porozumieniem między ewangelikami a stroną katolicką, gdyż ta nie była nim zainteresowana ${ }^{15}$. Rzadkie już publiczne wystąpienia skierowane przeciw odmiennym konfesjom, jak ostatnia debata w Rożnowie w $1660 \mathrm{r}^{16}$, miały raczej ograniczone oddziaływanie. Twierdzę tak, pamiętając, iż niektóre wydarzenia, jak kolokwium toruńskie w 1645 roku, angażowały uwage postronnych. Świadectwo temu dał wybitny szkocki intelektualista John Durie, zaś zawarte w Toruniu postanowienia przyjęte zostały przez kalwińskie kościoły Brandenburgii ${ }^{17}$. Ogłoszona po raz pierwszy we Frankfurcie w 1618 r. Fraterna et modesta [...] exhortatio Bartłomieja Bythnera była odpowiedzią na złożoną rzeczywistość konfesyjną i etniczną Krakowa. To wezwanie przedstawiciela małopolskich ewangelików reformowanych do zgody wszystkich chrześcijan i odejścia od podziałów wyznaniowych czytywane było w kolejnych dekadach oraz w XVIII stuleciu przez protestantów poza granicami Rzeczypospolitej ${ }^{18}$. Był to jednak raczej odosobniony głos; ocena praktycznego znaczenia tego i nielicznych podobnych stanowisk polskich irenistów poza granicami Rzeczypospolitej pozostaje jeszcze do wnikliwych ustaleń. Sądzę jednak, że w XVII-XVIII wieku polscy teolodzy, tak katoliccy, jak też ewangeliccy, nie mieli wiele do zaoferowania Europie. Uniwersytet w Krakowie, licznie odwiedzany przez młodzież różnych narodów w XV-XVI stuleciu, w kolejnych wiekach nie przyciągał sławą swych profesorów.

Wnikliwą analizę relacji między władcą, społeczeństwem, Parlamentem i Kościołem w Anglii XVI-XVII wieku przedstawił John Greville Agard Pocock. Prowadzi nas ona do odpowiedzi na pytanie o przyczyny nikłego zainteresowania na Wyspach odległymi, jak to określano, „wschodnimi ziemiami”, ale przede wszystkim ważna jest dla wskazania źródeł żywotności kultury religijnej tych narodów. W imperialnej polityce Henryka VIII, który inkorporował Walię do Anglii, zaś z Irlandii uczynił podporządkowaną jej monarchię, Kościół miał być podporą władzy królewskiej i gwarantem stabilizacji państwa. Elżbieta I jednoznacznie określiła w ten sposób rolę Kościoła już na początku swego panowania. Równie istotne, choć nieco inaczej sformułowane, było miejsce Kościoła w polityce Jakuba VI/I Stuarta, władcy trzech królestw. Lustrzanym odbiciem królewskiej supremacji w Anglii było

15 O tym m.in. ostatnio M. Paw ele c, Barttomiej Bythner..., s. 119-120 oraz szerzej: W. Kr r i g s e is en, Stosunki wyznaniowe w relacjach państwo-Kościót między reformacją a oświeceniem (Rzesza Niemiecka - Niderlandy Pótnocne - Rzeczpospolita polsko-litewska), Warszawa 2010, s. 576-594.

16 S. Rad oń, Z dziejów polemiki antyariańskiej w Polsce XVI-XVII wieku, Kraków 1993, s. 119-154.

17 A. Macinnes, The Hidden Commonwealth: Poland-Lithuania and Scottish Political Discourse in the Seventeenth Century, [w:] Citizenship and Identity in a Multinational Commonwealth: Poland-Lithuania in Context, 1550-1772, eds. K. Frie d rich, B.M. Pen dzich, Leiden-Boston 2009, s. 245-246, Studies in Central European Histories, 46.

18 Szerzej M. Pawelec, Barttomiej Bythner..., s. 53, 120. Zob. też W. Wake, D.E. Jablon ski, O. Odlo žilík, Protestant Reunion in the Eighteenth Century, „The Slavonic and East European Review” 1934, vol. 13, s. 124. 
zwierzchnictwo papieża-Antychrysta ${ }^{19}$. Odpowiedzią na próby przekonania do monarszej supremacji w sprawach wiary szkockich poddanych Stuartów było Narodowe Przymierze, zawiązane przez nich przeciw swemu władcy Karolowi I w 1638 roku. Jedyną głową Kościoła Szkocji miał pozostać Jezus Chrystus. Radykalizacja postaw wiodących w kierunku „czystej” religii szła w Anglii w parze z politycznym upodmiotowieniem społeczeństwa, co doprowadziło do pozbycia się „króla - tyrana” w 1649 roku. Gdy armia ukróciła reformatorskie zapędy prezbiterian, zwyciężyły idee wolności religijnej, w której obronie stać miał republikański rząd. Naszkicowane tu bardzo pobieżnie przemiany miały swą dynamiczną kontynuację w okresie restauracji monarchii, tj. po 1660 roku, gdy wróciły prześladowania nonkonformistów, zaś stałym dziedzictwem po latach republiki był tzw. sektarianizm. Jak zauważył David Rollison, relacje angielskiego społeczeństwa z władzą od czasów najazdu normańskiego do Restauracji to pasmo konfliktów. Autor ten określa „constitutional culture of early modern England, not in terms of alternatives, but as a fluid spectrum ranging between two poles, the «imperial» and «populist»"20. Inaczej, co nie oznacza, iż w pełnej harmonii, układały się relacje między władzą a społeczeństwem północnego królestwa Stuartów. Konflikty te rozstrzygano nie tylko mieczem czy wzniecając stosy, ale przede wszystkim piórem. Podczas szkockich „biskupich wojen” (1638, a ściślej 1639-1640) krwi przelano niewiele, za to spierające się strony wysłały w kierunku wroga przynajmniej 60 druków ${ }^{21}$.

Walczący o przetrwanie po 1660 roku angielscy nonkonformiści także chętnie wykorzystywali w swej obronie prasę drukarską. Polemizujący z nimi polscy katoliccy autorzy kontrowersyjni czasów saskich dają świadectwo, że jakaś część tej literatury trafiała do polskiego czytelnika, być może za pośrednictwem francuskich czy niemieckich tłumaczeń. Zagadnienie to wymaga jednak jeszcze gruntownych badań2 ${ }^{22}$. Niewątpliwie też należałoby podjąć planowane przed laty przez Marka Wajsbluma poszukiwania polskich śladów w angielskich kolekcjach kwakrów.

Sądzę, że właśnie takie wystąpienia w obronie wspólnych wartości, jak zarysowane wyżej społeczeństw Wysp Brytyjskich, troska o to, aby różnie postrzegany interes społeczny był należycie reprezentowany przez instytucje państwa, w tym Kościól, a jednocześnie

19 J.G.A. Po cock, The Discovery of Islands: Essays in British History, Cambridge 2005, s. 48-52; J. G o o d a r e, Scottish Politics in the Reign of James VI, [w:] The Reign of James VI, eds. J. Go od a re, M. Ly n ch, Edinburgh 2008, s. 32-54; nadto szerzej zob. L. F. Solt, Church and State in Early Modern England, 1509-1640, New York-Oxford 1990; 'Settling the Peace of the Church': 1662 Revisited, ed. N.H. Ke eble, New York-Oxford 2014.

20 D. Rollinson, A Commonwealth of the People: Popular Politics and England's Long Social Revolution, 1066-1649, Cambridge 2010, s. 430.

21 S. Waurechen, Covenanter Propaganda and Conceptualizations of the Public during the Bishops' Wars, „The Historical Journal” 2009, vol. 52, 1, s. 66, 63-86.

22 Zob. W. Kowalski, "Walking he preferred before talking". Roger Haydock, apostot Świattości w siedemnastowiecznej Anglii, [w:] Staropolska literatura dewocyjna, red. I. M. Dacka-Gór zy ńska, J. Pa r t yka, Warszawa 2015, s. 329-330, Staropolskie Teksty Paraliterackie, t. 3. 
tylko pozornie sprzeczne z tym dążenia do swobody kultu religijnego i wolności wypowiedzi, budowały siłę narodu i atrakcyjność jego kultury (czy kultur), często za cenę prześladowań, emigracji i ofiary życia. Takie uświadomione w wymiarze jednostkowym (np. Tomasz More) czy wspólnotowym (np. purytanie, kwakrzy) koszty ponoszone na rzecz realizacji naczelnego celu, jakim było osiągnięcie zbawienia, a przed tym stabilizacji życia społecznego w silnym, niezawisłym państwie, zdecydowanie różniły Brytanię od Rzeczypospolitej. Wczesnonowożytne protoindustrialne społeczności Anglii i Szkocji zdolne były do mobilizacji przeciw wrogom wewnętrznym (np. papiści) i zewnętrznym ze świadomością, że codzienna walka o byt, w sklepie, warsztacie czy z bronią w ręku, wiedzie ku lepszej przyszłości ${ }^{23}$. Nieliczne wczesnonowożytne polskie zabytki historiografii mieszczańskiej ukazują natomiast lokalne społeczności nastawione na przetrwanie pośród przeciwności losu, jak klęski elementarne. Opisywane tam jasne strony komunalnej egzystencji to głównie obrazy z wyidealizowanej przeszłości, gdy miasta otrzymywały swą prawną i ekonomiczną podmiotowość. Starania o utrzymanie municypalnych przywilejów z monarszej łaski zakreślały granice miejskiej polityki. Konsekwencje wywalczonych w obu porządkach politycznych ustrojów oraz przyjętych dróg rozwoju społecznego (a w tym ekonomicznego) były więc skrajnie różne i dlatego różny musiał być potencjał atrakcyjności i żywotności kultur tych narodów ${ }^{24}$. Oczywiście autorka stosownego rozdziału omawianego tomu dostrzega zależności między rozwojem gospodarczym, dążeniami społecznymi a dziełami kultury, ale sądzę, że to dobra okazja, aby zaakcentować je jeszcze dobitniej ${ }^{25}$.

Jeśli więc skonfrontujemy pobieżnie nakreślony wyżej obraz relacji społecznych w Anglii i Szkocji owych czasów z dość statycznym i - z odleglejszej perspektywy - w zasadzie jednowymiarowym stanem polskiej kultury szlachecko-katolickiej, to jasno widać, że brak tu propozycji atrakcyjnych dla obu stron. Wielce erudycyjnie przedstawione przez Mirosławę Hanusiewicz-Lavallee polskie oceny przemian religijnych na Wyspach w XVI - pierwszej połowie XVII wieku uzupełnić można udokumentowanym zainteresowaniem polskiego dworu losami kontrowersyjnej królowej Marii Stuart ${ }^{26}$. Wydaje się jednak, że w kolejnych dekadach obie strony coraz częściej odwoływały się do niekoniecznie usprawiedliwionych stereotypów. Szlachta polska, jak zauważył przed laty Janusz Tazbir, zgadzała się z krążącymi

23 O tym opowiada m.in. David Rollison w znakomitej, przywołanej wyżej, książce. W dzieje Szkocji już wiele dekad kompetentnie wprowadza w tej mierze T.C. S m o u t (A History of the Scottish People, 1560-1830, London 1998).

24 Zob. W. B a czkow sk a, Z rozważań nad historiografia mieszczańską XVI - początków XVIII w., „Zeszyty Naukowe Uniwersytetu Jagiellońskiego 709. Prace Historyczne” 1985, z. 77, s. 53-67.

25 Zob. M. Hanusiewicz-Lavallee, op. cit., s. 125-189. Znaczące rozwinięcie komentowanych tu ocen

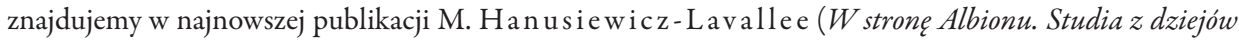
polsko-brytyjskich związków literackich w dobie wczesnonowożytnej, Lublin 2017, Studia i Materiały z Dziejów Literatury Wczesnonowożytnej, 4).

26 Szkocja Marii Stuart wedtug dwóch szesnastowiecznych manuskryptów z Biblioteki Jagiellońskiej, [oprac.] M. Misztal, Kraków 2004. 
po Europie opiniami o buntowniczym usposobieniu Anglików ${ }^{27}$. Nieodległa od tej musiała być opinia o Rzeczypospolitej przynajmniej części brytyjskiej klasy politycznej czasów Restauracji. Oto bowiem Anthony Ashley-Cooper, pierwszy hrabia Shaftsbury, przywódca Whigów konspirujących przeciw prawowitemu władcy, ośmieszony został przez torysowskich oponentów w ogłaszanych przez nich pamfletach jako Anthony King of Poland ${ }^{28}$. Znamienne, że - jak wnioskować można z opracowania Marcina Polkowskiego - nawet w Niderlandach, z którymi Rzeczypospolita utrzymywała ożywione kontakty w XVI-XVII wieku, w kolejnym stuleciu utrwalił się obraz „zacofanego Sarmaty”29.

Szkotów znano zaś, rzec można, z codziennych kontaktów i powszechne wyobrażenie tej nacji było w Rzeczypospolitej raczej negatywne. Świadectwo temu daje m.in. Wacław Potocki, np. gdy opowiada, jak to znany mu „nieuk, ale majętny szlachcic spod Lublina” wysłał swą latorośl do Gdańska w celu nauki języka niemieckiego. Syn „powrócił we trzy lata Szotem, ale to mniej/ Po niemiecku nie umie, po polsku zapomni”30.

Licząca najwyżej około 7 tysięcy osób część kontynentalnej diaspory szkockiej, która w XVI-XVII wieku osiadła w Rzeczypospolitej, nie pozostawiła tu w zasadzie świadectw, mogących przybliżyć kulturę tej społeczności. Dysponujemy jedynie nielicznymi źródłami informującymi o ich więzach z polskim i litewskim ewangelicyzmem reformowanym ${ }^{31}$. Nadzieję na istotne rozszerzenie tej wiedzy daje najstarsza biblioteka publiczna w Szkocji, założona w 1683 roku w Kirkwall na Orkadach, której zbiory przechowuje aktualnie Uniwersytet Aberdeen. Są tam m.in. publikacje okolicznościowe ogłaszane w Gdańsku i Krakowie, ale także druki związane z socynianami, co w sumie rzuca nieco światła na kontakty środowiskowe i horyzonty intelektualne przynajmniej niektórych szkockich imigrantów w Rzeczypospolitej ${ }^{32}$.

Jak powszechnie wiadomo, łacina odgrywała w paneuropejskiej wymianie idei w XVI-XVII wieku rolę niedającą się przecenić. Interesująco przedstawił ją Wiesław Pawlak,

27 J. Tazbir, Szlaki kultury polskiej, Warszawa 1986, s. 12.

${ }_{28}$ Zob. szerzej A. Macinnes, op. cit., s. 251. Nazwisko to występuje w indeksie (Wśród krajów Pótnocy, s. 158); nie pojawia się jednak na wskazanej stronie tego tomu.

29 M. Polkow ski, Rzeczpospolita a Niderlandy. Relacje literackie i kulturowe w dobie staropolskiej, [w:] W'sód krajów Pótnocy, s. 190-246, tu s. 227.

30 W. Potocki, Ogród nie plewiony i inne utwory z lat 1677-1695, [w:] Dzieta, t. 2, oprac. L. Kukulski, Warszawa 1987, s. 277. Nadto szerzej W. Ko w al s k i, The Reasons for the Immigration of Scots to the Polish Commonwealth in the Early Modern Period as outlined in Contemporary Opinions and Historiography, [w:] Scotland and Poland. Historical Encounters, 1500-2010, eds. T.M. D e v in e, D. He s s e, Edinburgh 2011, s. 38-50.

31 O tym szerzej P.P. B aje r, Scots in the Polish-Lithuanian Commonwealth, 16th to 18th Centuries. The Formation and Disappearance of an Ethnic Group, Leiden-Boston 2012, The Northern World, 57; W. Ko w alski, Wielka imigracja. Szkoci w Krakowie i Matopolsce w XVI-pierwszejpotowie XVII wieku, Kielce 2014. Nadto: W. Kow alski, Znaczenie szkockiej diaspory w spoteczeństwie staropolskim. Zarys problemu, [w:] Robert Wojciech Portius de Lanxeth, krośnieński mieszczanin, kupiec i fundator, Krosno 2018 (w druku).

32 Dr Kelsey Jackson Williams, University of Stirling, był łaskaw szerzej poinformować mnie o tych zbiorach, za co jestem mu wdzięczny. Zob. też informację Bibliotheck of Kirkwall, [on-line:] https://www.abdn. ac.uk/library/cld/8/ - 9 IX 2017. 
ukazując recepcję tą drogą kultury niemieckiej33. Nie budzi wątpliwości podkreślana przez autora zasługa niemieckich jezuitów dla przybliżania polskiemu czytelnikowi dzieł powstałych w tym kręgu kulturowym. Upomniałbym się jednak o Kwadrantyna, podopiecznego kardynała Stanisława Hozjusza i braniewskich ojców Towarzystwa Jezusowego, którego przemyślenia ogłoszono drukiem jako wzór postępowania na drodze konwersji z luteranizmu do katolicyzmu ${ }^{34}$. Jak dowodzi Krystyna Wierzbicka-Trwoga w swym wielce wartościowym studium o przekładach z języka niemieckiego na język polski w wiekach XV-XVIII ${ }^{35}$, ważną część tej twórczości stanowiła literatura religijna, co nie może zaskakiwać. W tym kontekście wspomnieć wypadałoby jednak jeszcze translatorski trud Eustachego Trepki $^{36}$, który niestety nie został doceniony na kartach omawianego zbioru.

O bogactwie kultury narodowej świadczy jednak przede wszystkim piśmiennictwo wernakularne, zaś o atrakcyjności kultury dla postronnych - siła oddziaływania języka narodowego. Niewiele można by wskazać udokumentowanych w ten sposób sukcesów kultury polskiej poza polonofilstwem rosyjskich elit intelektualnych w XVII-XVIII wieku, o czym interesująco pisze Eliza Małek ${ }^{37}$. Jakże odmiennie więc jawi się nam tak mierzona skuteczność oddziaływania języka angielskiego. W 1582 roku, a więc w epoce Williama Shakespeare'a, Richard Mulcaster (ca. 1531-1611), autor dzieł z zakresu pedagogiki, napisał w swym Elementarie: „The English tongue is of small reach, stretching no further than this island of ours, nay not there over all" ${ }^{38}$. Sytuacja ta zaczęła zmieniać się około

33 W. Pawlak, Barbara qua fuerant regna latina funt. Polsko-niemieckie zwiazki kulturalne XVI-XVIII wieku w perspektywie neolatynistyki, [w:] W'ród krajów Pótnocy..., s. 320-364.

34 Ibidem, s. 341. Kwestią otwartą pozostaje wkład w te relacje protektora nawróconego wychowanka zakonu, kardynała Hozjusza; zob. M. Kowalski, W. Kowalsk i, Droga Ewangelii, we wspólnocie Kościota... Katolickie wezwania do nawrócenia religijnego w szesnastowiecznej Polsce, [w:] Rycerze, wędrowcy, kacerze. Studia z historii średniowiecznej i wczesnonowożytnej Europy Środkowej, red. W. Kow alski, B. Wo jcie ch ow sk a, Kielce 2013, s. 263-276. Jeszcze dotkliwszą luką jest pominięcie tego zabytku przez K. Melle r, Potrydenckie konwersje protestantów na katolicyzm. Świadectwa piśmiennicze, [w:] Formowanie kultury katolickiej..., s. 300-350.

35 K. Wier zbicka-Trw og a, Przektady z jezyka niemieckiego na jezyk polski od XV do końca XVIII wieku, [w:] W'sód krajów Pótnocy..., s. 406-434.

36 Zob. J. Małłek, Prusy Książęce a reformacja w Polsce, „Komunikaty Mazursko-Warmińskie” 1983, nr 159, s. 9-17 oraz szerzej K. Kolbu sze w s ki, Postyllografia polska XVI i XVII w., Kraków 1921, s. 44-57.

37 E. Małek, Polsko-rosyjskie kontakty kulturowe w XV-XVIII wieku, [w:] Wśród krajów Pótnocy..., s. 478-553.

38 Za: O. Jes perse n, Growth and Structure of the English Language, Leipzig 1905, s. 246-247. Swego rodzaju posłowiem do omawianych tu problemów jest opinia tego autora o rywalizacji języków polskiego i niemieckiego: „It sometimes happens in a district of mixed nationalities that the population which is intellectually superior give up their own language because they can learn their neighbours' tongue while these are too dull to learn anything but their own: this is said by some to be the reason why in Posen and adjacent districts Polish is gaining ground over German, a fact which others ascribe to the greater fertility of the Poles"; ibidem, s. 248. Jespersen (1860-1943) był wybitnym językoznawcą, pionierem socjolingwistyki, wykładowcą języka angielskiego na uniwersytecie kopenhaskim; Otto Jespersen. Facets of his Life and Work, eds. A. J u u l, H.F. Ni els en, Amsterdam-Philadelphia 1989, Amsterdam Studies in the Theory and History of Linguistic Science. Series III, Studies in the History of the Language Sciences, 52. Zob. nadto komentarz do 
wiek później. Angielski z wielkim trudem, ale konsekwentnie i na stałe zadomawiał się na europejskich salonach w ciągu XVIII wieku. Jednak do języków narodowych przenikał nie tylko dzięki sukcesom brytyjskiej armii i dyplomacji, ale przede wszystkim za sprawą rzemieślników i kupców ${ }^{39}$. Jest to jakże wymowne świadectwo diametralnie różnych dróg rozwoju gospodarczego, a w konsekwencji potencjału kultur narodów Rzeczypospolitej i Brytanii. Zgodzić trzeba się z opinią Mirosławy Hanusiewicz-Lavallee, że to „słabość polityczna państwa odebrała [...] atrakcyjność propozycjom kulturowym wywodzącym się z Rzeczypospolitej”0. Przyczyn tej słabości szukałbym jednak głębiej - w porządku społecznym państwa ukształtowanym na przełomie średniowiecza i nowożytności, dopełnionym w kolejnych dekadach. Jeśli mierzyć kulturalną aktywność mieszczan i chłopów ich wkładem w piśmiennictwo narodowe, to był on znikomy (pomijam tu Prusy Królewskie). Nie miejsce tu jednak, aby wracać szerzej do przyczyn takiego stanu rzeczy.

Zagadnieniem, które domaga się choćby pobieżnego zasygnalizowania, jest kwestia: w jakiej mierze adaptacje szeroko pojętego piśmiennictwa trafiały poza krąg ówczesnej polskiej elity? Świadectw tego na kartach omawianych tomów znajdujemy niezbyt wiele, gdyż badania nad recepcją obcych wpływów kulturowych w Rzeczypospolitej wymagają systematycznych kontynuacji. A vista dodać można za Edwardem Potkowskim i Agnieszką Bartoszewicz, że teksty inspirowane radykalną husycką myślą docierały w XV wieku nawet do peryferyjnych ośrodków Wielkopolski, choć efektywność ich oddziaływania pozostaje poza kontrolą ${ }^{41}$. Wiadomo natomiast, że poznańska edycja Traktatu o modlitwie $i$ kontemplacji Piotra z Alkantary (1627) oraz wcześniejsza kolońska (1607) wspierać miały odnowę życia wewnętrznego w polskich środowiskach franciszkanów obserwantów ${ }^{42}$.

Wielkim nieobecnym na kartach omawianych tu tomów są polscy Żydzi. Europejskie konteksty ich miejsca w kulturze Rzeczypospolitej to przede wszystkim sława polskich szkół rabinackich oraz rola tak wybitnych postaci jak m.in. Mojżesz Isserles (ok. 1520-1572) ${ }^{43}$. Warta dostrzeżenia jest również obca inspiracja polskiej literatury oskarżającej wyznawców judaizmu o tzw. mordy rytualne $e^{44}$.

cytowanej tu opinii, który poczynił P.D. McD o n ald, Artefacts of Writing: Ideas of the State and Communities of Letters from Matthew Arnold to Xu Bing, Oxford-New York 2017, s. 130.

39 O. Jespers e n, op. cit., s. 247; R. Fili ip o v ić, English as a Word Donor to Other Languages of Europe, [w:] The English Language in Europe, ed. R. Ha r t $m$ a n n, Exter 1996, s. 37-38.

40 M. Hanusiewicz-Lavalle e, Wprowadzenie do tomu I, [w:] Wśród krajów Pótnocy..., s. 56.

41 A. Bartoszewicz, Urban Literacy in Small Polish Towns and the Process of 'Modernisation' of Society in the Later Middle Ages, [w:] Writing and the Administration of Medieval Towns: Medieval Urban Literacy, [vol.] 1, eds. M. Moster r, A. Ad a m sk a, Turhout 2014, s. 166, Utrecht Studies in Medieval Literacy, 27.

42 W. F. Murawiec, Piotr z Alkantary i popularyzacja w Polsce jego programu życia wewnętrznego $w$ XVII i XVIII wieku, „Folia Historica Cracoviensia”, 1997-1998, vol. 4-5, s. 160-169.

43 M. Raffeld, Isserles, Mosheh ben Yisra'el, [w:] YIVO Encyclopedia of Jews in Eastern Europe, Vol. 1, ed. G. D. Hun dert, New Haven-London 2008, s. 809-810.

44 Badania takie prowadzi obecnie M. Teter, The Iconography of Blood Libel: A European Story / Ikonogra- 
Bogactwo etniczne i kulturowe ówczesnej Europy, a w niej także Rzeczypospolitej, skłania do przemyśleń dróg dalszych studiów nad czynnikami warunkującymi intensywność wzajemnych kontaktów. Celowe byłoby, przykładowo, pójście śladem Fernanda Braudela i spojrzenie w ten sposób na kraje leżące wokół Morza Bałtyckiego. Lektura obu tomów rozpoczynających serię Kultura I Rzeczypospolitej w Dialogu z Europa skłania do refleksji, że owe dyskursy kulturowe dobrze oddają skomplikowaną naturę dziejów. Zdefiniowanie doniosłości czynników wpływających na dynamikę procesów społecznych stojących za wielością owych dyskursów to zajęcie, którego finał odsuwa się ad kalendas Grecas. Niemniej jednak, choć patrząc z perspektywy Rzeczypospolitej na świat, po drugiej stronie lustra widzimy raczej jego fragmenty niż szerszy horyzont, to nawet tak ograniczony ogląd czyni nas bogatszymi na przyszłość. Choć w różnym stopniu, wszystkie tomy serii Kultura Pierwszej Rzeczypospolitej w Dialogu z Europa dowodzą potrzeby i możliwości kontynuowania studiów szczegółowych oraz prac dokumentacyjnych i bibliograficznych poszerzających horyzont naszego spojrzenia na spuściznę intelektualną epoki ${ }^{45}$. Jest to, jak sądzę, jeden z trwałych walorów poznawczych omawianych tomów.

\section{BIBLIOGRAFIA}

\section{Źródło drukowane:}

Herbest B., Nauka prawego chrześcijanina, Kraków 1566.

Wydawnictwa źródłowe:

Potocki W., Dzieta, t. 2, oprac. L. Kukulski, Warszawa 1987.

Szkocja Marii Stuart wedtug dwóch szesnastowiecznych manuskryptów z Biblioteki Jagiellońskiej, [oprac.] M. Misztal, Kraków 2004.

\section{Opracowania:}

Baczkowska W., Z rozważań nad historiografia mieszczańska XVI - początków XVIII w., „Zeszyty Naukowe Uniwersytetu Jagiellońskiego 709. Prace Historyczne” 1985, z. 77, s. 53-67.

Bajer P.P., Scots in the Polish-Lithuanian Commonwealth, 16th to 18th Centuries. The Formation and Disappearance of an Ethnic Group, Leiden-Boston 2012, The Northern World, 57.

Bartoszewicz A., Urban Literacy in Small Polish Towns and the Process of 'Modernisation' of Society in the Later Middle Ages, [w:] Writing and the Administration of Medieval Towns: Medieval Urban Literacy, [vol.] 1, eds. M. Mostert, A. Adamska, Turhout 2014, s. 149-182, Utrecht Studies in Medieval Literacy, 27.

Buszewicz E., Koncepcja jedności Kościota i idea Polski katolickiej w twórczości pisarzy potrydenckich, [w:] Formowanie kultury katolickiej $w$ dobie potrydenckiej. Powszechność i narodowość katolicyzmu polskiego, red. J. Dąbkowska-Kujko, Warszawa 2016, s. 388-434, Kultura Pierwszej Rzeczypospolitej w dialogu z Europa. Hermeneutyka wartości, red. A. Nowicka-Jeżowa, t. 6.

fia oskarżeń o mord rytualny. Historia europejska, [w:] Blood: Uniting and Dividing / Krew tączy i dzieli, ed. M. St ola rska-Fro n ia, Warszawa 2017, s. 120-149 oraz przygotowywana monografia.

45 Zakres i znaczenie takich prac udokumentowali szeroko M. Choptiany i P. Wilczek we wprowadzeniu do przywołanego wyżej tomu: Antytrynitaryzm w Pierwszej Rzeczypospolitej, s. 7-14. 
Filipović R., English as a Word Donor to Other Languages of Europe, [w:] The English Language in Europe, ed. R. Hartmann, Exter 1996, s. 37-46.

Goodare J., Scottish Politics in the Reign of James VI, [w:] The Reign of James VI, eds. J. Goodare, M. Lynch, Edinburgh 2008, s. 32-54.

Gruchała J.S., Iucunda familia librorum. Humaniści renesansowi w świecie książki, Kraków 2002.

Hanusiewicz-Lavallee M., Brytania i Sarmacja - na krańcach Europy, [w:] Ws'ród krajów Pótnocy. Kultura Pierwszej Rzeczypospolitej wobec narodów germańskich, stowiańskich i naddunajskich. Mapa spotkań, przestrzenie dialogu, red. M. Hanusiewicz-Lavallee, Warszawa 2015, s. 125-189, Kultura Pierwszej Rzeczypospolitej $w$ dialogu z Europa. Hermeneutyka Wartości, t. 1, red. A. Nowicka-Jeżowa.

Hanusiewicz-Lavallee M., W stronę Albionu. Studia z dziejów polsko-brytyjskich związków literackich $w$ dobie wczesnonowożytnej, Lublin 2017, Studia i Materiały z Dziejów Literatury Wczesnonowożytnej, 4.

Jespersen O., Growth and Structure of the English Language, Leipzig 1905.

Juul A., Nielsen H.F., eds., Otto Jespersen. Facets of his Life and Work, Amsterdam 1989, Amsterdam Studies in the Theory and History of Linguistic Science. Series III, Studies in the History of the Language Sciences, 52.

Kieniewicz J., Hiszpania a Rzeczpospolita, [w:] W przestrzeni Potudnia. Kultura Pierwszej Rzeczypospolitej wobec narodów romańskich. Estetyka, prady i style, konteksty kulturowe, red. M. Hanusiewicz-Lavallee, Warszawa 2016, s. 387-404, Kultura Pierwszej Rzeczypospolitej $w$ dia$\log$ z Europa. Hermeneutyka wartości, red. A. Nowicka-Jeżowa, t. 2.

Kolbuszewski K., Postyllografia polska XVI i XVII w., Kraków 1921.

Kowalski M., Kowalski W., Droga Ewangelii, we wspólnocie Kościota... Katolickie wezwania do nawrócenia religijnego w szesnastowiecznej Polsce, [w:] Rycerze, wędrowcy, kacerze. Studia z historii średniowiecznej i wczesnonowożytnej Europy Środkowej, red. W. Kowalski, B. Wojciechowska, Kielce 2013, s. 263-276.

Kowalski W, The Reasons for the Immigration of Scots to the Polish Commonwealth in the Early Modern Period as outlined in Contemporary Opinions and Historiography, [w:] Scotland and Poland. Historical Encounters, 1500-2010, eds. T. M. Devine, D. Hesse, Edinburgh 2011, s. 38-50.

Kowalski W., „Walking he preferred before talking”. Roger Haydock, apostot Świattości w siedemnastowiecznej Anglii, [w:] Staropolska literatura dewocyjna, red. I.M. Dacka-Górzyńska, J. Partyka, Warszawa 2015, s. 319-330, Staropolskie Teksty Paraliterackie, t. 3.

Kowalski W., Wielka imigracja. Szkoci w Krakowie i Matopolsce w XVI - pierwszej potowie XVII wieku, Kielce 2014.

Kowalski W., Znaczenie szkockiej diaspory w spoteczeństwie staropolskim. Zarys problemu, [w:] Robert Wojciech Portius de Lanxeth, krośnieński mieszczanin, kupiec i fundator, Krosno 2018.

Kriegseisen W., Autonomia jednostki a wolność sumienia. Problem konwersji w nowożytnej Rzeczypospolitej, [w:] Autonomia jednostki w Europie i w Polsce od XVII do XX wieku, red. W. Mędrzecki, Warszawa 2011, s. 25-44.

Kriegseisen W., Stosunki wyznaniowe w relacjach państwo-kościót między reformacją a ówieceniem (Rzesza Niemiecka - Niderlandy Pótnocne - Rzeczpospolita polsko-litewska), Warszawa 2010.

Krzak K., Pobożność popularna w ilustracjach modlitewników drukowanych w Polsce XVI wieku, [w:] Sztuka okoto 1500. Materiaty sesji Stowarzyszenia Historyków Sztuki. Gdańsk, listopad 1996, red. T. Hrankowska, Warszawa 1997, s. 299-312.

Kürbis B., Metody źródtoznawcze wczoraj i dziś, [w:] eadem, Cztery eseje o źródtoznawstwie, wstęp i dobór tekstów R. Witkowski, Poznań 2007, Klasycy Nauki Poznańskiej, t. 13, red. A. Pihan-Kijasowa, s. 104-119. 
Macinnes A., The Hidden Commonwealth: Poland-Lithuania and Scottish Political Discourse in the Seventeenth Century, [w:] Citizenship and Identity in a Multinational Commonwealth: Poland-Lithuania in Context, 1550-1772, eds. K. Friedrich, B. M. Pendzich, Leiden-Boston 2009, s. 233-260, Studies in Central European Histories, 46.

Małek E., Polsko-rosyjskie kontakty kulturowe w XV-XVIII wieku, [w:] . Kultura Pierwszej Rzeczypospolitej wobec narodów germańskich, stowiańskich i naddunajskich. Mapa spotkań, przestrzenie dialogu, red. M. Hanusiewicz-Lavallee, Warszawa 2015, s. 478-553, Kultura Pierwszej Rzeczypospolitej w dialogu z Europa. Hermeneutyka wartości, red. A. Nowicka-Jeżowa, t. 1.

Małłek J., Prusy Ksiązęce a reformacja w Polsce, „Komunikaty Mazursko-Warmińskie” 1983, nr 159, s. 9-17.

McDonald P.D., Artefacts of Writing: Ideas of the State and Communities of Letters from Matthew Arnold to Xu Bing, Oxford-New York 2017.

Meller K., Potrydenckie konwersje protestantów na katolicyzm. Świadectwa piśmiennicze, [w:] Formowanie kultury katolickiej w dobie potrydenckiej. Powszechność i narodowość katolicyzmu polskiego, red. J. Dąbkowska-Kujko, Warszawa 2016, s. 300-350, Kultura Pierwszej Rzeczypospolitej w dia$\operatorname{logu} z$ Europa. Hermeneutyka wartości, red. A. Nowicka-Jeżowa, t. 6.

Murawiec W.F., Piotr z Alkantary ipopularyzacja w Polsce jego programu życia wewnętrznego w XVII i XVIII wieku, „Folia Historica Cracoviensia”, 1997-1998, vol. 4-5, s. 153-169.

Nowak Z., Jan Danyszek. Portret renesansowego humanisty, Wrocław 1982, Biblioteka Towarzystwa Przyjaciót Gdańska.

Nowicka-Jeżowa A., Ad lectorem. Zarys projektu badawczego, [w:] W'sód krajów Pótnocy. Kultura Pierwszej Rzeczypospolitej wobec narodow germańskich, stowiańskich i naddunajskich. Mapa spotkań, przestrzenie dialogu, red. M. Hanusiewicz-Lavallee, Warszawa 2015, s. 7-47, Kultura Pierwszej Rzeczypospolitej w Dialogu z Europa. Hermeneutyka Wartości, red. A. Nowicka-Jeżowa, t. 1.

Partyka J., Kobiety a hiszpańska obecność w kulturze dawnej Rzeczypospolitej. Wybrane aspekty, [w:] W przestrzeni Potudnia. Kultura Pierwszej Rzeczypospolitej wobec narodow romańskich. Estetyka, prądy i style, konteksty kulturowe, red. M. Hanusiewicz-Lavallee, Warszawa 2016, s. 430-448, Kultura Pierwszej Rzeczypospolitej $w$ dialogu z Europa. Hermeneutyka wartości, red. A. Nowicka-Jeżowa, t. 2.

Pawelec M., Barttomiej Bythner starszy (ok. 1559-1629). Z dziejów protestanckiego irenizmu na przetomie XVI i XVII wieku, Warszawa 2008.

Pawlak W., Barbara que fuerant regna latina funt. Polsko-niemieckie związki kulturalne XVI-XVIII wieku w perspektywie neolatynistyki, [w:] W'ród krajów Pótnocy. Kultura Pierwszej Rzeczypospolitej wobec narodow germańskich, stowiańskich i naddunajskich. Mapa spotkań, przestrzenie dialogu, red. M. Hanusiewicz-Lavallee, Warszawa 2015, s. 320-364, Kultura Pierwszej Rzeczypospolitej $w$ dialogu $z$ Europa. Hermeneutyka wartości, red. A. Nowicka-Jeżowa, t. 1.

Pelc J., Stowo i obraz na pograniczu literatury i sztuk plastycznych, Kraków 2002.

Pocock J.G.A., The Discovery of Islands: Essays in British History, Cambridge 2005.

Polkowski M., Rzeczpospolita a Niderlandy. Relacje literackie i kulturowe w dobie staropolskiej, [w:] W'ród krajów Pótnocy. Kultura Pierwszej Rzeczypospolitej wobec narodow germańskich, stowiańskich i naddunajskich. Mapa spotkań, przestrzenie dialogu, red. M. Hanusiewicz-Lavallee, Warszawa 2015, s. 190-246, Kultura Pierwszej Rzeczypospolitej w dialogu z Europa. Hermeneutyka wartości, red. A. Nowicka-Jeżowa, t. 1.

Rabiej S., Herbest, Herbestus Neapolitanus, Benedykt SJ, [w:] Encyklopedia katolicka, t. 4, red. J. Walkusz, Lublin 1993, kol. 741.

Radoń S., Z dziejów polemiki antyariańskiej w Polsce XVI-XVII wieku, Kraków 1993. 
Raffeld M., Isserles, Mosheh ben Yisra'el, [w:] YIVO Encyclopedia of Jews in Eastern Europe, Vol. 1, ed. G.D. Hundert, New Haven-London 2008, s. 809-810.

Rollinson D., A Commonwealth of the People: Popular Politics and England's Long Social Revolution, 1066-1649, Cambridge 2010.

'Settling the Peace of the Church': 1662 Revisited, ed. N. H. Keeble, New York-Oxford 2014.

Smout T.C., A History of the Scottish People, 1560-1830, London 1998.

Solt L.F., Church and State in Early Modern England, 1509-1640, New York-Oxford 1990.

Tazbir J., Szlaki kultury polskiej, Warszawa 1986.

Teter M., The Iconography of Blood Libel: A European Story / Ikonografia oskarżeń o mord rytualny. Historia europejska, [w:] Blood: Uniting and Dividing / Krew taczy i dzieli, ed. M. Stolarska-Fronia, Warszawa 2017, s. 120-149.

Urjasz-Raczko M., Duma i uprzedzenia. Strategia dyplomacji hiszpańskiej wobec pierwszych wolnych elekcji w Rzeczypospolitej, [w:] Wprzestrzeni Potudnia. Kultura Pierwszej Rzeczypospolitej wobec narodow romańskich. Estetyka, prady i style, konteksty kulturowe, red. M. Hanusiewicz-Lavallee, Warszawa 2016, s. 405-429, , Kultura Pierwszej Rzeczypospolitej w dialogu z Europa. Hermeneutyka wartości, red. A. Nowicka-Jeżowa, t. 2.

Wake W., Jablonski D.E., Odložilík O., Protestant Reunion in the Eighteenth Century, „The Slavonic and East European Review", vol. 13, 1934, s. 119-126.

Waurechen S., Covenanter Propaganda and Conceptualizations of the Public during the Bishops' Wars, „The Historical Journal” 2009, vol. 52, issue 1, s. 63-86.

Wierzbicka-Trwoga K., Przektady z jezyka niemieckiego na jezyk polski od XV do końca XVIII wieku, [w:] W'ród krajów Pótnocy. Kultura Pierwszej Rzeczypospolitej wobec narodow germańskich, stowiańskich i naddunajskich. Mapa spotkań, przestrzenie dialogu, red. M. Hanusiewicz-Lavallee, Warszawa 2015, s. 406-434, Kultura Pierwszej Rzeczypospolitej w dialogu z Europa. Hermeneutyka wartości, red. A. Nowicka-Jeżowa, t. 1.

Wilczek P., Polonice et Latine. Studia o literaturze staropolskiej, Katowice 2007.

Włodarski M., Obraz i stowo. O powiazaniach w sztuce i literaturze XV-XVI wieku na przyktadzie „ars moriendi”, Kraków 1991.

Wojtyniak M., Rzeczpospolita i Hiszpania w kregu europejskiej respublica litteraria, [w:] W przestrzeni Potudnia. Kultura Pierwszej Rzeczypospolitej wobec narodow romańskich. Estetyka, prądy i style, konteksty kulturowe, red. M. Hanusiewicz-Lavallee, Warszawa 2016, s. 449-468, , Kultura Pierwszej Rzeczypospolitej w dialogu z Europa. Hermeneutyka wartości, red. A. Nowicka-Jeżowa, t. 2

$W$ przestrzeni Potudnia. Kultura Pierwszej Rzeczypospolitej wobec narodów romańskich. Estetyka, prady i style, konteksty kulturowe, red. M. Hanusiewicz-Lavallee, Warszawa 2016, Kultura Pierwszej Rzeczypospolitej w dialogu z Europa. Hermeneutyka wartości, red. A. Nowicka-Jeżowa, t. 2.

W'ród krajów Pótnocy. Kultura Pierwszej Rzeczypospolitej wobec narodów germańskich, stowiańskich i naddunajskich. Mapa spotkań, przestrzenie dialogu, red. M. Hanusiewicz-Lavallee, Warszawa 2015, Kultura Pierwszej Rzeczypospolitej $w$ dialogu z Europa. Hermeneutyka wartości, t. 1, red. A. Nowicka-Jeżowa.

Wyczawski H.E., Herbest (Herbestus, Neapolitanus) Benedykt, [w:] Stownikpolskich teologów katolickich, t. 2, red. H.E. Wyczawski, Warszawa 1982, s. 36-37. 